\title{
Validasi Konstruk Inventori Adaptasi Inovasi Kirton Dalam Bahasa Indonesia
}

\author{
Gracia Tobing, ${ }^{1}$ Veronika Efata Angelina, ${ }^{1}$ Dea Franceline, ${ }^{1}$ Morina Yuandary Anwar, ${ }^{1}$ \\ Christiany Suwartono, ${ }^{2}$ Magdalena Halim ${ }^{2}$ \\ Fakultas Psikologi Universitas Katolik Indonesia Atma Jaya/Himpunan Psikologi \\ Indonesia Wilayah DKI Jakarta \\ J1. Jenderal Sudirman 51, Jakarta Pusat \\ sisie_gracia@yahoo.com,christiany.suwartono@atmajaya.ac.id \\ ${ }^{1}$ Mahasiswa Program Magister Profesi Psikologi Universitas Katolik Indonesia Atma Jaya. \\ ${ }^{2}$ Dosen Fakultas Psikologi Universitas Katolik Indonesia Atma Jaya.
}

\begin{abstract}
Every human is a problem solver. Humans always have to deal with different kinds of problems that needs to be resolved. We have our own way to solve our problem even if they face the same one. This is because humans have different cognitive style. How a person sees and solves his/her problems shows their cognitive style. The way we solve a problem is also can be an indicator of how creative a person is. Kirton's Adaption-Innovation (KAI) Inventory was created to measure creativity style. This research was dedicated to adapt into Indonesian version of KAI Inventory. We used convenience sampling method and got 164 participants. We did measurement model for the confirmatory factor analysis. Then the psychometric tests have been done to ensure its reliability and validity. Based on the results of Inter-item Correlation, Correlation With Another Tests method, and Factor Analysis showed that Indonesian version of KAI Inventory was reliable but still needs some revision on its items to increase its validity.
\end{abstract}

Keywords: construct validation; factor analysis; creativity style; Kirton Adaption, Innovation Inventory; test adaptation.

\begin{abstract}
Abstrak-Semua orang adalah pemecah masalah, karena ia selalu berhadapan dengan berbagai masalah di kehidupannya yang harus diselesaikan. Masing-masing orang memiliki cara penyelesaian masalah yang berbeda meskipun dihadapkan pada masalah yang serupa karena ia memiliki gaya berpikir yang berbeda-beda. Gaya berpikir ini dapat diamati dari caranya melihat dan menyelesaikan masalahnya. Cara ia menyelesaikan masalah bisa jadi merupakan indikator paling baik untuk menunjukkan kreativitas seseorang. Kirton memandang kreativitas sebagai cara seseorang dalam menunjukkan kreativitasnya. Hal ini disebut Kirton sebagai creativity style yang diukur dengan alat ukur Kirton's Adaption-Innovation (KAI). Penelitian ini bertujuan untuk mengadaptasi KAI ke dalam Bahasa Indonesia. Kami menggunakan metode convenience sampling. Kami melakukan validasi konstruk dengan menggunakan faktor analisis konfirmatori, khususnya tipe measurement model. Pengujian psikometri dilakukan untuk memastikan reliabilitas dan validitas KAI
\end{abstract}


versi Bahasa Indonesia. Hasil pengujian Inter-Item Correlation, Correlation With Another Tests serta Factor Analysis menunjukkan bahwa KAI versi Bahasa Indonesia ini cukup reliabel namun membutuhkan revisi pada beberapa itemnya untuk meningkatkan validitasnya.

Kata kunci: validasi konstruk; faktor analisis; gaya kreativitas; Inventori Adaptasi, Inovasi Kirton; adaptasi alat ukur.

\section{PENDAHULUAN}

Dalam kehidupan manusia, manusia tidak pernah lepas dari berbagai permasalahan di setiap aspek kehidupannya. Masalah-masalah tersebut membutuhkan penyelesaian agar manusia dapat melanjutkan kehidupannya dengan baik. Kirton (1976) tertarik untuk mengetahui cara manusia menyelesaikan masalahnya. Ia berpendapat bahwa manusia memiliki cara penyelesaian masalah yang berbeda-beda, meskipun dihadapkan pada masalah yang serupa. Hal ini terjadi karena manusia memiliki cara berpikir (cognitive style) yang berbeda-beda. Cognitive style merupakan suatu konstruk yang tidak kasat mata, sehingga tidak dapat diukur secara langsung. Akan tetapi, cognitive style ini dapat diamati dari cara manusia melihat dan menyelesaikan masalahnya.

Terkait dengan cara manusia menyelesaikan masalah, Gardner (dalam Stum, 2009) menyatakan bahwa cara penyelesaian masalah tersebut merupakan indikator paling baik untuk menunjukkan kreativitas seseorang. Kreativitas digambarkan sebagai kemampuan individu untuk menciptakan sesuatu yang baru dari yang sudah ada. Dalam berbagai penelitian tentang kreativitas, terdapat dua pendekatan utama yang digunakan untuk memahami kreativitas, yaitu kreativitas dilihat sebagai level/tingkat dan kreativitas dilihat sebagai gaya (Isaksen \& Puccio, 1988). Pada pendekatan pertama, kreativitas diukur untuk menunjukkan kualitas dari kemampuan seseorang dalam berkreasi. Pada pendekatan ke dua, pengukuran terhadap kreativitas dilakukan dengan melihat preferensi seseorang yang ditunjukkan secara konsisten dalam mengekspresikan kreativitasnya (Isaksen \& Puccio, 1988). Kirton memandang kreativitas bukan sebagai suatu tingkatan atau kapasitas yang dimiliki seseorang, tetapi lebih merupakan cara atau gaya seseorang dalam menunjukkan kreativitasnya. Hal ini disebut Kirton sebagai creativity style yang diukur dengan alat ukur Kirton's Adaption-Innovation (KAI).

Dalam proses pembuatan alat ukur KAI, Kirton melakukan observasi terhadap perilaku para pemimpin (manager) ketika menyelesaikan suatu masalah ataupun dalam mengambil keputusan (Kirton, 1976). Berdasarkan hasil penelitiannya, Kirton (1976) mengambil kesimpulan bahwa terdapat dua kelompok manager dengan pendekatan yang berbeda dalam menghadapi masalah, yaitu kelompok adaptor (to do things better) dan kelompok innovator (to do things differently). Meski demikian, bukan berarti tipe adaptor lebih baik daripada innovator, dan sebaliknya tipe innovator tidak lebih baik daripada adaptor.

Secara teoritis, skor KAI memiliki skor minimum 32 dan skor maksimal 160. Kirton menetapkan bahwa alat ukur KAI terdiri dari tiga faktor. Faktor pertama, Style of Originality (SO), mengacu pada preferensi seseorang dalam mengembangkan atau menciptakan ide-ide baru. Kemudian faktor kedua, Style of Efficiency (E), mengacu pada preferensi seseorang untuk dapat bekerja dengan teliti, tepat, reliabel, dan efisien. Faktor ketiga, Style of Rule/Group Conformity (R), mengacu pada preferensi seseorang untuk berperilaku dalam aturan, kebijakan, dan struktur.

Alat ukur Kirton Adaption-Innnovation ini terdiri dari 32 item dengan pilihan jawaban politomi. Partisipan diminta untuk menilai tingkat kesulitannya dalam menampilkan perilaku sesuai dengan pernyataan 
pada masing-masing item yang diwakili dengan pilihan jawaban: sangat sulit, sulit, netral, mudah, sangat mudah. Skor yang diperoleh partisipan dari respon jawaban dari setiap item berkisar antara 1-5.

Berikut merupakan pengelompokan nomor item berdasarkan domain yang diwakilinya dalam alat ukur KAI (Kirton, 1976):

Tabel 1. Domain dan Item Alat Ukur KAI versi Michael Kirton

\begin{tabular}{ll}
\hline \multicolumn{1}{c}{ Domain } & \multicolumn{1}{c}{ Nomor Item } \\
\hline Style of Originality (SO) & $1,2,3,4,5,6,7,8,9,10,11,12,13$ \\
Style of Efficiency (E) & $14,15,16,17,18,19,20$ \\
Style of Rule/Group Conformity (R) & $21,22,23,24,25,26,27,28,29,30,31,32$ \\
\hline
\end{tabular}

Alat ukur KAI yang mampu membedakan creativity style individu ke dalam tipe adaptor dan tipe innovator ini dapat berguna dalam membentuk kelompok-kelompok dalam organisasi. Johnson (2003) menyatakan bahwa kelompok yang paling baik adalah kelompok yang terdiri dari beberapa orang dengan gaya kreativitas yang bervariasi.

\section{METODE}

\section{Partisipan}

Terkait dengan aplikasi alat ukur KAI di dunia kerja, populasi penelitian dari proses adaptasi KAI di Indonesia adalah seluruh pekerja aktif di Indonesia. Dalam proses adaptasi KAI, penelitian ini melibatkan 54 partisipan dalam proses pengambilan data try out dan 164 partisipan dalam proses pengambilan data field. Tidak terdapat perbedaan kriteria partisipan dalam proses tryout maupun proses field. Adapun kriteria dari partisipan dalam adaptasi alat ukur KAI ini adalah aktif bekerja, laki-laki/perempuan, usia 21-55 tahun, dan level pendidikan minimum setingkat SMU. Dalam pengambilan data untuk kepentingan adaptasi alat ukur KAI, tim peneliti menggunakan teknik pengambilan sampel dengan metode convenience sampling, di mana penentuan sampel ditentukan berdasarkan kemudahan peneliti (Patton, 2002).

\section{Desain}

Partisipan dalam penelitian ini diperoleh dengan metode kenyamanan sehingga semua orang yang sesuai dengan kriteria yang sudah kami tetapkan dan kami temui, bisa menjadi partisipan. Penelitian ini merupakan penelitian adaptasi alat ukur psikologis yang kemudian menguji validitas alat tes tersebut dengan menggunakan faktor analisis. Tim melakukan proses adaptasi seperti yang disarankan Brislin (1970) dan Hambleton, Merenda, dan Spielberg (2005). Ada pun yang digunakan dalam melakukan validasi konstruk adalah tipe confirmatory factor analysis, khususnya measurement model.

\section{Prosedur}

Dalam proses adaptasi alat ukur KAI, terdapat beberapa tahapan yang dilakukan oleh tim peneliti. Pertama kali, kami melakukan kajian literatur terkait proses penyusunan alat ukur KAI oleh Kirton pada 
tahun 1976, beserta dengan literatur-literatur lain terkait pengembangan alat ukur terssebut serta adaptasi KAI di berbagai negara. Kemudian, kami melakukan kajian literatur untuk menentukan alat ukur yang dapat dijadikan alat ukur pembanding dari KAI. Berdasarkan hasil kajian literatur pada beberapa jurnal, tim peneliti sepakat untuk menggunakan alat ukur MBTI sebagai alat ukur pembanding dari KAI. Setelah itu, kami melakukan penerjemahan alat ukur. Untuk mendapatkan hasil terjemahan yang baik terdapat dua metode yaitu forward translation dan backward translation (Hambleton dalam Hambleton, Merenda, \& Spielberg, 2005). Dalam melakukan forward translation peneliti dibantu oleh empat orang di luar tim peneliti yang memiliki kemampuan bahasa Inggris baik, sedangkan dalam backward translation peneliti dibantu oleh seorang rekan di luar tim peneliti dengan kemampuan bahasa Inggris baik. Langkah-langkah yang dilakukan adalah melakukan forward translation, tim peneliti menentukan item bahasa Indonesia dari setiap item yang disepakati bersama, serta dilakukan backward translation. Setelah item-item final KAI berbahasa Indonesia disusun, peneliti melakukan pengambilan data untuk tahap try out. Tahap ini dilakukan di minggu kedua Oktober 2012 dengan melibatkan 54 orang partisipan dengan latar belakang yang beragam. Selanjutnya, kami melakukan uji psikometri analisis item terhadap data-data yang diperoleh berdasarkan hasil uji coba. Hasilnya menunjukkan terdapat beberapa item yang kurang baik sehingga membutuhkan revisi. Kami kemudian melakukan revisi terhadap item-item yang kurang baik. Setelah melakukan revisi item, peneliti melakukan pengambilan data untuk tahap field. Tahap ini berlangsung pada minggu kedua November 2012 dengan melibatkan 164 partisipan. Peneliti melakukan uji psikometri untuk mendapatkan nilai validitas, reliabilitas dan norma dari alat ukur KAI yang diadaptasi ke Bahasa Indonesia. Hasil ini kemudian dituangkan dalam manual alat ukur KAI.

\section{Teknik Analisis}

Pengujian Psikometri.Analisis item dalam penelitian ini dilakukan secara kualitatif maupun secara kuantitatif. Analisis kualitatif dilakukan dengan melihat bentuk dan isi item. Sedangkan, analisis kuantitatif dilakukan dengan melihat item discrimination. Item dengan hasil perhitungan corrected item-total correlation dengan nilai koefisien korelasi lebih besar dari 0.3 maka item akan dipertahankan (Okolo, 1991). Akan tetapi, pada kenyataannya, alat ukur KAI mengambil nilai minimal sebesar 0.2 karena berdasarkan hasil pengambilan data, masih terdapat cukup banyak item dalam alat ukur KAI ini yang berada pada rentang 0.2-0.3.

Konstruk creativity style merupakan konstruk unidimensional sehingga item-item yang ada pada alat ukur Kirton Adaption-Innovation merupakan item-item yang sifatnya homogen. Sumber error yang mungkin terjadi karena sifat kehomogenitasan ini adalah heterogeneity differences, yaitu kondisi di mana item-item dalam suatu alat ukur tidak mengukur satu konstruk yang sama. Selain itu, karena item-item yang digunakan pada alat ukur ini diambil dari pool item, maka sumber error lain yang mungkin terjadi pada saat pengerjaan alat ukur ini adalah content-sampling error. Berdasarkan pada dua kemungkinan error yang terjadi, metode uji reliabilitas yang dipilih pada alat ukur KAI ini adalah single trial reliability untuk melihat inter-item consistency dengan teknik statistik coefficient alpha. Menurut Kaplan dan Sacuzzo (1982), nilai koefisien reliabilitas minimal untuk basic research adalah sebesar 0.7 .

Pengujian validitas alat ukur KAI menggunakan uji construct validity yang dilakukan dengan tiga cara, yaitu metode internal consistency, factor analysis serta correlation with other tests. Alat ukur MBTI digunakan sebagai alat ukur pembanding, di mana KAI dikorelasikan dengan domain Extraversion (E) vs Introversion (I), Sensing (S) vs. Intuition (N) dan Judging $(J)$ vs Perceiving (P) pada MBTI sebagai convergent validity. Discriminate 
validity juga akan diuji dengan mengkorelasikan alat ukur KAI dengan domain Thinking (T) vs. Feeling (F). Hal ini sesuai dengan berbagai penelitian telah dilakukan untuk menguji hubungan antara KAI dengan MBTI dalam Lattanzio (2002). Alat ukur MBTI yang digunakan adalah MBTI versi Bahasa Indonesia yang dikembangkan oleh Mudrika (2009), dengan rentang koefisien reliabilitas di setiap domain berkisar antara 0.66-0.71. Hal ini menunjukkan bahwa reliabilitas dari MBTI ini masih berada pada tahap sedang (De Vellis, 1991).

Norma yang digunakan untuk memaknai alat ukur KAI adalah within group norms, di mana skor total individu pada alat ukur KAI dibandingkan dengan skor kelompoknya. Kirton (1976) menyatakan bahwa terdapat perbedaan skor KAI yang signifikan antara laki-laki dan perempuan, karena itu within-group norms pada alat ukur KAI dibedakan berdasarkan jenis kelamin. Hal ini dilakukan dengan mencari nilai rata-rata dari distribusi skor KAI pada masing-masing kelompok, yaitu kelompok laki-laki dan perempuan. Total skor yang diperoleh individu dari alat ukur KAI kemudian dibandingkan dengan nilai rata-rata kelompoknya berdasarkan jenis kelamin. Apabila skor yang diperoleh di atas nilai rata-rata kelompok, maka individu tersebut dikategorikan memiliki creativity style innovator. Sebaliknya, jika skor yang diperoleh di bawah nilai rata-rata kelompok, maka individu tersebut dikategorikan memiliki creativity style adaptor.

Skoring Alat Ukur Kirton Adaption-Innovation (KAI). Berdasarkan sifat itemnya, ketigapuluhdua item dalam alat ukur ini terdiri dari dua kelompok item, yaitu item favourable dan item unfavourable. Pembagian item berdasarkan sifatnya ini akan mempengaruhi cara pemberian nilai/poin partisipan pada masing-masing item. Ada pun contoh untuk item favourable "saya adalah orang yang memiliki ide-ide orisinal" sedangkan untuk item unfavourable "saya adalah orang yang menguasai suatu hal dengan susah payah". Berikut merupakan pembagian antara item positif (favourable) dan item negatif (unfavourable) pada alat ukur KAI:

Tabel 2. Item-Item Favourable dan Unfavourable

\begin{tabular}{lc}
\hline \multicolumn{1}{c}{ Jenis Item } & Nomor Item \\
\hline Item favourable & $1,2,3,4,5,6,7,8,9,10,11,12,13,18$ \\
Item unfavourable & $14,15,16,17,19,20,21,22,23,24,25,26,27,28,29,30,31,32$ \\
\hline
\end{tabular}

Cara melakukan skoring pada item positif(favourable) adalah dengan memberikan nilai satu sampai lima sesuai dengan pilihan jawaban pada alat ukur, yaitu nilai 1 jika partisipan memilih pilihan jawaban (1) sangat sulit, serta nilai 5 jika partisipan memilih pilihah jawaban (5) sangat mudah. Untuk item negatif (unfavourable) skoring dilakukan dengan memberi nilai lima sampai satu untuk pilihan jawaban satu sampai lima di alat ukur, yaitu nilai 1 jika partisipan memilih pilihan jawaban (5) sangat mudah, serta nilai 5 jika partisipan memilih pilihah jawaban (1) sangat sulit. Skor total partisipan pada alat ukur KAI diperoleh dengan menjumlahkan skor partisipan pada setiap item. Skor total dari alat ukur KAI berkisar antara 32 (merupakan nilai terendah yang mungkin diperoleh) sampai 160 (merupakan nilai tertinggi yang mungkin diperoleh).

\section{ANALISIS \& HASIL}

\section{Gambaran Partisipan}

Berdasarkan jenis kelamin, proporsi partisipan laki-laki dan perempuan pada saat try out kurang seimbang, yaitu sebanyak $26 \%$ laki-laki dan $67 \%$ perempuan. Sedangkan, pada saat field, proporsi jenis kelamin antara 
laki-laki dan perempuan cukup seimbang, yaitu sebanyak 52\% laki-laki dan $48 \%$ perempuan. Berdasarkan usia, partisipan dikelompokkan menjadi kelompok usia di bawah 30 tahun, 30-44 tahun, dan 45 tahun ke atas. Pada saat try out, proporsi partisipan usia di bawah 30 tahun sebesar 67\%, usia 30-44 tahun sebesar 20\%, usia 45 tahun ke atas sebesar 4\%, dan tidak diketahui usianya sebesar $9 \%$. Sedangkan saat field, proporsi partisipan usia di bawah 30 tahun sebesar 70\%, usia 30-44 tahun sebesar 26\%, dan usia 45 tahun ke atas sebesar 4\%.

\section{Analisis Item}

Data skor KAI yang diperoleh pada tahap try out, diuji dengan menggunakan perhitungan psikometri untuk mengidentifikasi item yang baik dan item yang membutuhkan revisi ataupun buruk. Menurut Okolo (1991), item yang dianggap memiliki daya pembeda untuk individu dengan atribut tinggi maupun atribut rendah ialah item yang memiliki koefisien korelasi lebih dari 0.3. Namun standar koefisien korelasi yang digunakan peneliti adalah sebesar 0.2. Dari hasil perhitungan, terdapat beberapa item KAI yang memiliki corrected itemtotal correlation di atas 0.2 , yaitu item 1, 2, 3, 4, 5, 6, 7, 8, 9, 11, 20, 22, 23, 24, 25, 28, 29, dan 31 .

Dengan demikian, dapat disimpukan bahwa item-item tersebut memiliki daya yang signifikan untuk membedakan individu yang memiliki gaya kreativitas innovator dengan individu yang memiliki gaya kreativitas adaptor. Dari hasil perhitungan, juga terdapat item-item dengan corrected item-total correlation di bawah 0.2, yaitu item 10,12,13, 14, 15, 16, 17, 18, 19,21, 26, 27, 30, dan 32. Dapat disimpulkan bahwa item-item tersebut memiliki daya yang tidak signifikan dalam membedakan individu yang memiliki gaya kreativitas innovator dengan individu yang memiliki gaya kreativitas adaptor. Oleh karena itu item-item tersebut perlu direvisi.

\section{Reliabilitas}

Setelah melakukan uji reliabilitas menggunakan teknik statistik Cronbach's Alpha, didapatkan koefisien reliabilitas sebesar 0.701. Dari hasil tersebut, dapat diartikan bahwa $70.1 \%$ varians merupakan varians true score dan $29.9 \%$ varians merupakan varians error, yaitu content sampling error dan heterogeneity differences. Menurut Kaplan dan Sacuzzo (1993), koefisien reliabilitas minimum ialah sebesar 0.7. Dengan demikian, dapat disimpulkan bahwa, item-item dalam alat ukur KAI secara konsisten dapat mengukur konstruk yang sama.

Berdasarkan hasil tersebut, maka dapat dihitung pula nilai standard error of measurement. Standard error of measurement dalam alat ukur ini ialah sebesar 5.08. Dengan begitu, pada level of confidence 95\%, true score berada pada rentang nilai: raw score \pm 9.96 .

\section{Validitas}

Berdasarkan hasil pengujian validitas internal, terdapat item-item yang kurang baik jika dilihat dari corrected item-total correlation yang memiliki nilai di bawah 0.2 dan/atau negatif. Item-item tersebut antara lain item $6,10,13,14,15,17,18,19,20,21$, dan 28. Berdasarkan hasil tersebut maka dapat diartikan bahwa item-item tersebut tidak mengukur satu konstruk yang sama dengan item-item lainnya. Item-item tersebut memiliki corrected item-total correlation diasumsikan disebabkan oleh dua hal. Pertama, terdapat item yang membuat partisipan cenderung untuk menjawab secara normatifjika dilihat dari penyebaran respon item (antara lain item 10, 13, 14, 19, 21, dan 28). Kedua, terdapat item di mana pengkalimatan isi kurang begitu jelas sehingga membuat partisipan mengalami kesulitan dalam menjawab (antara lain, item 6, 15, 17, 18, dan 20). 
Dalam pengujian validitas konstruk eksternal menggunakan metode correlation with other tests, alat ukur KAI dibandingkan dengan alat ukur MBTI. Berikut hasil perhitungan uji korelasi antara alat ukur KAI dengan MBTI:

Tabel 3. Hasil Uji Validitas Eksternal Alat Ukur KAI Dengan Alat Ukur MBTI

\begin{tabular}{lcc}
\hline \multicolumn{1}{c}{ KAI - Domain MBTI } & $\mathrm{r}$ & p-value \\
\hline Introversion & -.29 & .00 \\
Extraversion & .29 & .00 \\
Sensing & .56 & .00 \\
Intuition & .56 & .00 \\
Judging & -.33 & .00 \\
Perceiving & .33 & .00 \\
Thinking & .08 & .31 \\
Feeling & -.08 & .32 \\
\hline
\end{tabular}

Berdasarkan hasil perhitungan korelasi Pearson Product Moment, didapatkan koefisien korelasi yang signifikan antara skor KAI dengan beberapa domain MBTI, yaitu dengan domain Introversion, Extraversion, Intuition, Sensing dan Judging, Perceiving. Semakin tinggi skor KAI diikuti dengan semakin tinggi skor domain Introversion, Extraversion, Intuition, Sensing atau pun Judging, Perceiving. Dengan kata lain, alat ukur KAI memiliki convergent validity yang signifikan dengan ketiga domain tersebut. Hasil tersebut sejalan dengan hasil penelitian Hughes (1994), di mana telah terbukti bahwa creativity style berkorelasi signifikan dengan domain Introversion, Extraversion, Intuition, Sensing ataupun Judging, Perceiving.

Alat ukur KAI memiliki convergent validity yang signifikan dengan domain Introversion, Extraversion dalam MBTI disebabkan karena creativity style, khususnya innovator memiliki kesamaan trait dengan Extravert. Individu yang Extravert menggunakan energinya ke dunia luar. Mereka sangat menyukai diskusi dengan orang lain, terutama untuk mendapatkan ide-ide baru. Hal ini sejalan dengan innovator yang juga memiliki kebutuhan untuk mengungkapkan ide-idenya dan mendapatkan timbal balik akan ide-idenya. Alat ukur KAI memiliki convergent validity yang signifikan dengan domain Intuition, Sensing dalam MBTI disebabkan karena creativity style, khususnya innovator memiliki kesamaan trait dengan Intuitor. Individu yang Intuitor cenderung menyukai wawasan baru, pencerahan dan imajinasi. Hal ini juga sejalan dengan innovator yang juga menggunakan imajinasi dan konsep-konsep baru dalam membentuk ide baru. Domain Judging, Perceiving dalam MBTI juga terbukti signifikan dalam uji convergent validity dengan alat ukur KAI disebabkan karena creativity style, khususnya innovator juga memiliki kesamaan trait dengan Perceivers. Seorang Perceivers cenderung bersikap fleksibel, spontan, cepat menyesuaikan diri dengan perubahan. Hal ini sejalan dengan innovator yang menyukai, bahkan membutuhkan perubahan dalam pekerjaannya.

Berdasarkan hasil perhitungan korelasi Pearson Product Moment, didapatkan juga koefisien korelasi yang tidak signifikan antara skor KAI dengan domain MBTI, yaitu Thinking, Feeling. Dengan kata lain, alat ukur KAI memiliki discriminant validity dengan domain tersebut. Hasil tersebut juga sejalan dengan hasil penelitian Hughes (1994). Hal ini disebabkan karena creativity style tidak melihat kecenderungan seseorang dalam menggunakan logika ataupun perasaan saat mengambil keputusan. Dengan penjelasan di atas, maka alat ukur KAI yang telah diadaptasi secara valid mengukur konstruk creativity style. 
Dalam pengujian factor analysis untuk alat ukur KAI, dilakukan exploratory factor analysis untuk mengidentifikasi faktor-faktor utama yang menjelaskan sebagian besar varians variabel-variabel yang diobservasi. Pengujian exploratory factor analysis terhadap skor KAI, didapatkan hasil sebagai berikut:

Tabel 4. Factor Loading Item pada Tiap Faktor

\begin{tabular}{|c|c|c|c|c|c|c|c|c|c|c|}
\hline \multirow{2}{*}{$\begin{array}{c}\text { No } \\
\text { Item }\end{array}$} & \multicolumn{10}{|c|}{ Faktor/Domain } \\
\hline & 1 & $\|$ & III & IV & V & $\mathrm{VI}$ & VII & VIII & IX & $x$ \\
\hline 1 & -.021 & .487 & -.091 & .368 & .380 & .029 & -.010 & .077 & .030 & .073 \\
\hline 2 & -.029 & .551 & -.004 & .378 & .214 & .179 & -.180 & -.063 & .001 & .050 \\
\hline 3 & .082 & .419 & .115 & .286 & .066 & .102 & -.250 & .440 & .156 & -.005 \\
\hline 4 & .132 & .721 & -.028 & -.062 & .039 & .046 & -.049 & .187 & .103 & -.154 \\
\hline 5 & -.068 & .718 & -.084 & .189 & .102 & -.045 & .091 & -.059 & .005 & -.111 \\
\hline 6 & -.036 & .007 & -.052 & .687 & -.095 & .038 & .036 & .263 & .037 & .039 \\
\hline 7 & -.054 & .271 & -.042 & .710 & .065 & .071 & -.026 & -.055 & -.069 & -.036 \\
\hline 8 & .319 & .379 & .038 & .460 & .155 & .021 & .076 & .178 & .223 & -.182 \\
\hline 9 & .229 & .140 & -.147 & .342 & .212 & .248 & .169 & .044 & .404 & -.269 \\
\hline 10 & -.079 & -.356 & -.181 & .024 & -.083 & -.121 & -.526 & -.042 & . 270 & -.186 \\
\hline 11 & .251 & .148 & -.012 & .183 & .072 & -.088 & -.182 & .618 & .005 & -.135 \\
\hline 12 & .303 & .230 & .161 & .212 & .143 & .079 & .260 & .404 & .043 & -.181 \\
\hline 13 & -.139 & .188 & -.052 & -.032 & -.054 & -.086 & -.671 & .122 & -.144 & -.028 \\
\hline 14 & .025 & -.057 & .840 & -.091 & -.093 & .145 & .005 & -.007 & .048 & .058 \\
\hline 15 & .166 & .077 & .373 & .019 & .017 & .022 & -.090 & -.657 & -.061 & -196 \\
\hline 16 & .361 & -.069 & .483 & .203 & .198 & -.201 & .189 & -.026 & .022 & .315 \\
\hline 17 & .158 & -.024 & .809 & -.070 & -.131 & .052 & .113 & -.088 & -.068 & .037 \\
\hline 18 & .128 & .003 & .146 & .134 & .025 & -.136 & .108 & .119 & .776 & .030 \\
\hline 19 & .106 & -.149 & .187 & .234 & -.203 & -.034 & .355 & .126 & -.641 & .049 \\
\hline 20 & .328 & -.091 & .120 & .091 & .289 & .151 & -.270 & -.117 & -.401 & -.181 \\
\hline 21 & .025 & -.272 & .087 & .016 & -.009 & -.041 & .032 & -.060 & -.015 & .746 \\
\hline 22 & .024 & 140 & -.036 & -.011 & .796 & -.103 & .005 & .070 & .091 & .000 \\
\hline 23 & -.045 & -.070 & .131 & .171 & .481 & .270 & .316 & .365 & -.059 & -.291 \\
\hline 24 & .745 & .075 & .074 & .019 & -.017 & .022 & .064 & .057 & .009 & .122 \\
\hline 25 & .763 & -.035 & .052 & -.140 & -.008 & .198 & -.118 & .148 & .053 & .068 \\
\hline 26 & .637 & -.031 & .073 & .013 & .001 & .008 & .304 & -.086 & -.033 & -179 \\
\hline 27 & .300 & .213 & .084 & -.200 & .109 & .134 & .420 & .140 & .002 & .491 \\
\hline 28 & .019 & .151 & -.136 & .006 & .656 & .103 & .047 & -.018 & .026 & .059 \\
\hline 29 & .240 & -.024 & -.075 & .043 & -.032 & .701 & .191 & -.256 & -.010 & -.008 \\
\hline 30 & .002 & .314 & .221 & .133 & -.096 & .632 & .205 & .018 & -.004 & .039 \\
\hline 31 & .531 & .106 & .251 & .114 & .083 & .329 & .138 & .002 & .092 & .370 \\
\hline 32 & .112 & -.058 & .110 & .029 & .246 & .681 & -.200 & .248 & -.175 & -.053 \\
\hline
\end{tabular}

Hasil perhitungan di atas menunjukkan bahwa alat ukur KAI terdiri dari 10 faktor dengan loading factor sesuai tabel di atas. Setelah mendapatkan 10 faktor ini, item-item kemudian dianalisis secara kualitatif 
berdasarkan isi dari setiap item dan teori yang digunakan oleh Kirton (1976) saat menentukan penamaan faktor saat Kirton membuat alat ukur KAI. Berdasarkan hasil analisis kualitatif tersebut, dirumuskan empat faktor utama dari alat ukur KAI sebagai berikut:

Tabel 5. Domain dan Item Alat Ukur KAI Adaptasi

\begin{tabular}{ll}
\hline \multicolumn{1}{c}{ Domain } & \multicolumn{1}{c}{ Nomor Item } \\
\hline Style of Originality (SO) & $1,2,3,4,5,6,7,8,9,12$ \\
Style of Efficiency (E) & $10,13,14,15,16,17,18,19$ \\
Style of Conformity (R) & $11,20,21,22,23,24,25,26,28,31$ \\
Style of Security (S) & $27,29,30,32$ \\
\hline
\end{tabular}

Setelah melakukan penentuan faktor-faktor dan juga penamaannya, dilanjutkan dengan Confirmatory Factor Analysis. Berikut hasil uji unidimensionalitas dari keempat faktor dari KAI:

Tabel 6. Hasil Uji Unidimensionalitas

\begin{tabular}{|c|c|c|c|c|c|c|}
\hline Faktor/Dimensi & $x^{2}$ & df & $\begin{array}{l}p \text {-value } \\
(>0.05)\end{array}$ & $\begin{array}{l}\text { RMSEA } \\
(<0.10)\end{array}$ & $\begin{array}{c}\text { GFI } \\
(>0.9)\end{array}$ & Keterangan \\
\hline $\begin{array}{l}\text { Style of Originality } \\
\text { (SO) }\end{array}$ & 36.52 & 25 & 0.64 & 0.05 & .96 & $\begin{array}{l}\text { Item-item dalam faktor ini } \\
\text { mengukur dimensi yang } \\
\text { sama setelah } 10 \text { kali modifi- } \\
\text { kasi error }\end{array}$ \\
\hline Style of Efficiency (SE) & 19.36 & 15 & .20 & .04 & .97 & $\begin{array}{l}\text { Item-item dalam faktor ini } \\
\text { mengukur dimensi yang } \\
\text { sama setelah } 5 \text { kali modifi- } \\
\text { kasi error }\end{array}$ \\
\hline $\begin{array}{l}\text { Style of Conformity } \\
\text { (SC) }\end{array}$ & 42.41 & 30 & .07 & .05 & .95 & $\begin{array}{l}\text { Item-item dalam faktor ini } \\
\text { mengukur dimensi yang } \\
\text { sama setelah } 5 \text { kali modifi- } \\
\text { kasi error }\end{array}$ \\
\hline Style of Security (SS) & 2.92 & 2 & .23 & .05 & .99 & $\begin{array}{l}\text { Item-item dalam faktor ini } \\
\text { mengukur dimensi yang } \\
\text { sama tanpa modifikasi } \\
\text { error }\end{array}$ \\
\hline
\end{tabular}

Berdasarkan hasil pengujian unidimensionalitas, masing-masing faktor dapat melanjutkan pengujian confirmatory factor analysis berikutnya yaitu first order test. Setelah dilakukan pengujian first order analysis, didapatkan bahwa keempat faktor tidak berhubungan satu dengan yang lain karena gagal memenuhi persyaratan lulus uji first order test, walaupun dilakukan modifikasi error sebanyak 25 kali $\left(\chi^{2}=736.22\right.$, $p$-value $=0.000$, RMSEA $=0.066$, dan GFI $=0.78)$. 


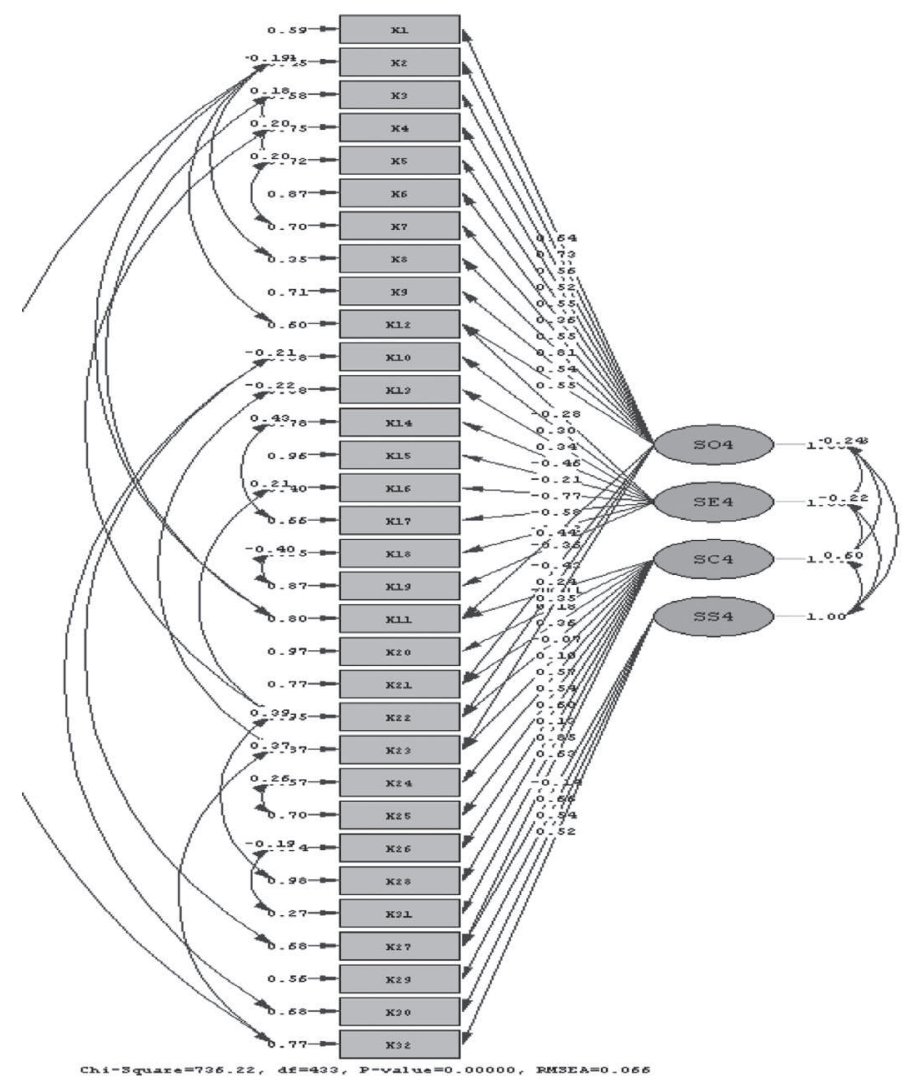

Bagan 1. Model Uji First Order - Confirmatory Factor Analysis

Hasil pengujian ini diperiksa kembali dengan melakukan uji korelasi antar faktor.

Tabel 7. Hasil Uji Korelasi Antar Faktor

\begin{tabular}{lcccc}
\hline \multicolumn{1}{c}{ Faktor } & SO & SE & SC & SS \\
\hline SO & - & - & - & - \\
SE & -.06 & - & - & - \\
SC & $.36^{* *}$ & $.16^{*}$ & - & - \\
SS & $.26^{* *}$ & .07 & $.42^{* *}$ & - \\
\hline
\end{tabular}

Keterangan:

** Signifikan pada LoS .01

SO (Style of Originality), SE (Style of Efficiency), SC (Style of Conformity), SS (Style of Security)

Berdasarkan hasil uji korelasi, ditemukan bahwa terdapat satu faktor, yaitu Style of Efficiency, yang tidak berkorelasi secara signifikan dengan faktor lainnya. Style of Efficiency hanya berkorelasi dengan Style of Conformity. Hal ini yang mungkin menyebabkan uji first order KAI tidak berhasil dilalui. Jika melihat corrected item total correlation kembali, item-item yang termasuk dalam domain Style of Efficiency memang merupakan item yang tidak mengukur konstruk yang sama dengan item-item lainnya. 


\section{Norma}

Norma untuk alat ukur KAI dibedakan berdasarkan jenis kelamin. Kelompok sampel perempuan yang digunakan sebagai kelompok norma telah terbukti memiliki distribusi skor normal $\left(Z_{(75)}=0.09, p=0.20\right)$. Begitu juga dengan kelompok sampel laki-laki yang digunakan sebagai kelompok norma juga terbukti memiliki distribusi skor normal $\left(Z_{(85)}=0.09, p=0.06\right)$. Kedua kelompok sampel tersebut telah terbukti memiliki perbedaan yang signifikan $\left(t_{(158)}=-2.25, p=0.03\right)$. Hal ini sejalan dengan penelitian Kirton(1976) yang menyatakan bahwa terdapat perbedaan mean skor KAI pada kelompok laki-laki dan perempuan.

Penggunaan mean kelompok sebagai patokan untuk menentukan individu dengan creativity style adaptor atau pun innovator ialah karena kreativitas diukur oleh KAI bukan sebagai suatu tingkatan, namun sebagai suatu preferensi. Dengan kata lain, alat ukur ini tidak digunakan untuk mengetahui apakah seseorang merupakan seorang innovator atau pun adaptor dengan tingkat kreativitas tinggi atau rendah. Berikut mean yang digunakan sebagai acuan intepretasi skor KAI.

Tabel 8. Mean Kelompok Perempuan dan Laki-laki

\begin{tabular}{lccc}
\hline \multicolumn{1}{c}{ Jenis Kelamin } & N & M & SD \\
\hline Perempuan & 75 & 95.88 & 7.49 \\
Laki-laki & 85 & 98.86 & 9.08 \\
\hline
\end{tabular}

Kirton (1976) mengemukakan beberapa karakteristik dasar dari tipe innovator maupun tipe adaptor. Kedua tipe ini berada pada kubu yang bertolak belakang dalam memandang dan menghadapi suatu permasalahan/situasi. Pada dasarnya individu dengan tipe innovator adalah individu yang memiliki kepercayaan diri tinggi. Mereka suka melakukan segala sesuatu dengan cara yang berbeda dari yang biasa dipergunakan banyak orang lainnya. Selain itu, mereka juga mampu melihat suatu hal/permasalahan dari sudut pandang yang berbeda dari orang lain.

Karakteristik lain dari tipe innovator adalah ketertarikannya terhadap perubahan. Mereka cenderung kurang menyukai pekerjaan yang rutin, detil dan monoton. Sebaliknya, merasa senang saat berhadapan dengan perubahan dan bahkan siap membuat perubahan itu sendiri. Tipe innovator sangat membutuhkan fleksibilitas dalam menjalankan pekerjaannya. Akibatnya, dalam menghadapi suatu permasalahan, tipe innovator sering kali dianggap sebagai sosok yang suka melanggar aturan. Mereka juga cenderung kurang peka terhadap perasaan dan pemikiran orang lain, berpeluang lebih besar untuk berkonflik dengan orang lain.

Bertolak belakang dengan tipe innovator, individu dengan tipe adaptor mementingkan ketepatan, keajegan, dan efisiensi dalam melaksanakan pekerjaannya. Tipe adaptor memandang aturan sebagai acuan dan panduan yang harus diikuti untuk mendapatkan hasil yang terbaik dalam pekerjaan, sehingga mereka cenderung lebih disiplin. Selain itu, pada dasarnya tipe adaptor merupakan individu yang tidak terlalu percaya diri, karenanya mereka tidak suka membuat hal-hal baru. Mereka lebih suka melakukan perbaikan dari situasi yang dihadapi daripada membuat perubahan baru untuk mengatasi masalah.

Dalam berelasi dengan orang lain, tipe adaptor adalah individu yang mementingkan hubungan baik dengan orang lain. Oleh karena itu, tipe adaptor lebih peka terhadap perasaan dan pemikiran orang lain. Mereka juga berusaha menghindari konflik dengan orang lain, sehingga lebih suka mengikuti kemauan dan pemikiran orang lain daripada memperjuangkan pendapat pribadinya. Individu dengan tipe adaptor merasa nyaman saat berada di posisi yang sama dengan kebanyakan orang lain. 


\section{DISKUSI}

Peneliti menyimpulkan bahwa alat ukur KAI tidak memiliki validitas internal yang baik, jika dilihat berdasarkan hasil uji internal consistency dan factor analysis, diduga diakibatkan oleh beberapa hal. Salah satunya ialah akibat bias yang dapat mempengaruhi pengukuran (Hambleton, Merenda, \& Spielberger, 2005). Bias terjadi karena adanya faktor-faktor yang tidak berhubungan dengan tujuan alat ukur yang mempengaruhi pengukuran (Vijver \& Poortinga dalam Hambleton, Merenda, \& Spielberger, 2005). Bias yang terjadi dalam alat ukur KAI ini ialah instrument bias yang termasuk dalam kategori method bias. Instrument bias terjadi karena adanya faktor-faktor dari properti-properti pengukuran yang mempengaruhi hasil pengukuran padahal tidak berhubungan dengan tujuan dari pengukuran itu sendiri. Dalam alat ukur KAI instrument bias terletak pada alternatif jawaban yang disediakan pada alat ukur tidak terlalu cocok dengan pernyataan -pernyataan pada masing-masing item. Akibatnya partisipan kesulitan untuk memahami makna item, yang akhirnya cenderung memberi respon jawaban "seadanya."

Jenis bias yang juga terjadi pada proses adaptasi alat ukur KAI ini adalah item bias, di mana terdapat fungsi item yang berbeda dari fungsi item aslinya. Dalam alat ukur KAI, hal ini terjadi karena penerjemahan item yang kurang baik, seperti konotasi yang tidak tepat atau adanya item yang bermakna ambigu (Vijver \& Poortinga dalam Hambleton, Merenda, \& Spielberger, 2005). Hal ini menyebabkan partisipan kesulitan untuk memahami makna dari item, sehingga respon yang diberikan kurang menggambarkan keadaan dirinya. Item-item sejenis ini dapat dikategorikan sebagai item yang buruk sehingga membutuhkan perbaikan.

Pengadaptasian alat ukur Kirton Adaption-Innovation Inventory ke dalam bahasa Indonesia ini sebelumnya pernah dilakukan oleh B.P Dwi Riyanti pada tahun 2001. Dalam adaptasi alat ukur KAI yang diadaptasi oleh Riyanti (2001), didapatkan hasil 3 faktor/domain sesuai dengan alat ukur KAI asli yang dibuat oleh Kirton. Sementara, dalam penelitian ini didapatkan hasil 4 faktor/domain. Perbedaan ini mungkin dipengaruhi oleh beberapa hal seperti pada saat proses translating-back translating, Riyanti (2001) memasukkan/memperhatikan konteks yang ada di Indonesia, sehingga item menjadi lebih mudah dipahami oleh partisipan dan partisipan dapat memberi respon yang sesuai dengan keadaan dirinya.

Tabel 9. Contoh Perbandingan Penerjemahan Item Alat Ukur KAI

\begin{tabular}{cccc}
\hline No & Item Asli & Versi Peneliti & Versi Riyanti (2001) \\
\hline 22 & Conforms & Ikut-ikutan & Mudah menyesuaikan diri \\
\hline
\end{tabular}

Selain itu, pilihan respon pada alat ukur KAI yang diadaptasi oleh Riyanti menggunakan pilihan Sangat Tidak Sesuai (STS) sampai Sangat Sesuai (SS). Pilihan respon ini dirasa lebih sesuai dengan item-item dalam alat ukur KAI daripada pilihan respon Sangat Sulit (SS) sampai Sangat Mudah (SM) yang digunakan oleh peneliti. Kemudian, pilihan respon pada alat ukur KAI yang diadaptasi oleh Riyanti menggunakan 6 skala respon yaitu Sangat Tidak Sesuai, Tidak Sesuai, Agak Tidak Sesuai, Agak Sesuai, Sesuai, Sangat Sesuai. Hal ini meminimalisir kemungkinan partisipan untuk memberi respon netral terhadap item. Pada alat ukur KAI versi peneliti, pilihan jawaban netral tersedia sehingga partisipan cenderung memilih jawaban netral pada item yang dirasa sulit untuk mempermudah dalam memberikan jawaban. 


\section{SIMPULAN \& SARAN}

\section{Simpulan}

Alat ukur Kirton Adaption-Innovation Inventory (KAI) yang diadaptasi ke dalam Bahasa Indonesia ini belum dapat dipergunakan secara luas di lingkungan masyarakat Indonesia karena belum memenuhi kriteria alat ukur yang baik. Hal ini dapat dilihat dari hasil uji psikometri data yang diperoleh dari lapangan (data field). Meskipun berdasarkan standar reliabilitas Kaplan dan Saccuzo (1993) hasil pengujian reliabilitas alat ukur KAI dengan nilai koefisien alpha sebesar .70 dapat dikatakan cukup baik, namun hasil pengujian validitas konstruknya tidak demikian.

Metode pengujian konstruk dengan internal consistency menunjukkan bahwa terdapat 11 item dari alat ukur KAI yang kurang baik, yaitu item 6, 10, 13, 14, 15, 17, 18, 19, 20, 21, dan 28. Item-item ini perlu diperbaiki karena beberapa di antaranya terdiri dari kalimat yang sulit dimengerti, sehingga menyulitkan partisipan dalam memberikan respon. Penyebab lainnya adalah pernyataan pada beberapa item bersifat kurang netral sehingga membuat partisipan merespon secara normatif dan tidak merepresentasikan keadaan diri partisipan apa adanya. Hal ini menunjukkan bahwa item-item dalam alat ukur KAI di atas belum dapat mengukur konstruk yang sama dengan yang diukur item lainnya.

Pengujian konstruk dengan metode Confirmatory Factor Analysis juga menunjukkan bahwa domain dalam alat ukur KAI belum secara bersama-sama mengukur konstruk. Dari hasil uji unidimensionalitas, keempat domain atau faktor dalam KAI menunjukkan bahwa item-item pada masing-masing faktor terbukti mengukur faktor tersebut. Hanya saja keempat faktor ini tidak secara bersama-sama mengukur konstruk yang sama. Hal ini ditunjukkan oleh gagalnya pengujian first order dalam uji Confirmatory Factor Analysis (CFA).

Pada penelitian sebelumnya (Hughes, 1994), tipologi kepribadian yang diukur MBTI terbukti secara signifikan berhubungan dengan creativity style yang diukur oleh KAI. Meski kedua metode pengujian validitas konstruk sebelumnya menunjukkan bahwa alat ukur KAI tidak mengukur satu konstruk yang sama, namun metode correlation with other test menunjukkan bahwa KAI secara signifikan memiliki convergent validity dengan tiga dimensi MBTI, yaitu Introversion, Extraversion, Intuition, Sensing, dan Judging, Perceiving. Sesuai dengan penelitian sebelumnya (Hughes, 1994), alat ukur KAI juga terbukti memiliki discriminant validity karena tidak berkorelasi secara signifikan dengan domain Thinking, Feeling. Berdasarkan data-data di atas, dapat disimpulkan bahwa konstruk yang diukur KAI secara valid mengukur creativity style.

\section{Saran}

Untuk meminimalisir kemungkinan bias yang pada akhirnya mempengaruhi kualitas dari performance alat ukur KAI, baik bias method maupun bias item disarankan untuk pengembangan adaptasi dari alat ukur ini untuk lebih memperhatikan konteks dari masing-masing item dalam proses penerjemahan item, sehingga partisipan dapat lebih mudah memahami pernyataan dalam item. Selain itu, tidak menggunakan alternatif jawaban "sangat sulit" hingga "sangat mudah", seperti yang digunakan dalam format alat ukur asli KAI. Alternatif jawaban ini dirasa menyulitkan bagi sebagian partisipan untuk memberikan respon. Disarankan untuk menggunakan alternatif jawaban "sangat sesuai" hingga "sangat tidak sesuai" pada alat ukur KAI. Terakhir, dalam penggunaan alat ukur KAI, item no. 6, 10, 13, 14, 15, 17, 18, 19, 20, 21, dan 28 perlu dipertimbangkan karena item-item tersebut tidak mengukur satu konstruk yang sama dengan item-item lainnya. 


\section{DAFTAR PUSTAKA}

Brislin, R.W. (1970). Back-Translation for Cross Cultural Research. Journal of Cross-Cultural Psychology, $1(3), 185-216$.

De Vellis, R. F. (1991). Scale Development: Theory and Applications. California: Sage.

Hambleton, R. K., Merenda, P. F., \& Spielberger, C. D. (2005). Adapting Educational and Psychological Tests for Cross-Cultural Assessment. New Jersey: Lawrence Erlbaum.

Hughes, M. A. (1994). Myers-Briggs Type Indicators and Kirton Adaption-Innovation Inventory Correlations. Executive Research Project. Washington DC: The Industrial College of the Armed Forces National Defense University.

Isaksen, S. G. \& Puccio, G. J. (1988). Adaption-Innovation and the Torrance Tests of Creative Thinking: The Level-Style Issue Revisited. Psychological Reports, 63, 659-670.

Johnson, R. C. (2003). Study of the Relationship Between Cognitive Styles of Creativity and Personality Types of Military Leaders. Proquest Dissertations and Theses.

Kaplan, R. M. \& Sacuzzo, D. P. (1982). Psychological Testing: Principles, Applications, and Issues (3 ${ }^{\text {rd }}$ Ed.). California: Brooks/Cole.

Kirton, M. (1976). Adaptors and Innovators: A Description and Measure. Journal of Applied Psychology, 61(5), 622-629.

Lattanzio, G. A. (2002). The Myers-Briggs Type Indicator Meets the Kirton Adaption-Innovation Inventory: An Executive Summary of Sundell's 1999 Master's Project. State University of New York, International Center for Studies in Creativity.

Okolo, E. N. (1991). Health Research Design and Methodology. USA: CRC Press.

Patton, M. Q. (2002). Qualitative Research and Evaluation Methods. Thousand Oaks: Sage Pub.

Riyanti, B. P. D. (2001). Faktor-Faktor yang Berpengaruh terhadap Keberhasilan Usaha Skala Kecil di DKI dan DIY. Disertasi. Jakarta: Universitas Indonesia.

Stum, J. (2009). Kirton's Adaption-Innovation Theory: Managing Cognitive Styles in Times of Diversity and Change. Emerging Leadership Journeys, 2 Iss(1), 66-78.

\section{Internet}

Mudrika, N .(2009). Skala MBTI. Diunduh online 21 September 2012 pada http://nafismudrika.wordpress.com 